\title{
Blazing and grazing: influences of fire and bison on tallgrass prairie stream water quality
}

\author{
Author(s): Danelle M. Larson , Bartosz P. Grudzinski , Walter K. Dodds , Melinda D. Daniels , Adam Skibbe and
} Anthony Joern

Source: Freshwater Science, 32(3):779-791. 2013.

Published By: The Society for Freshwater Science

DOI: http://dx.doi.org/10.1899/12-118.1

URL: http://www.bioone.org/doi/full/10.1899/12-118.1

BioOne (www.bioone.org) is a nonprofit, online aggregation of core research in the biological, ecological, and environmental sciences. BioOne provides a sustainable online platform for over 170 journals and books published by nonprofit societies, associations, museums, institutions, and presses.

Your use of this PDF, the BioOne Web site, and all posted and associated content indicates your acceptance of BioOne's Terms of Use, available at www.bioone.org/page/terms of use.

Usage of BioOne content is strictly limited to personal, educational, and non-commercial use. Commercial inquiries or rights and permissions requests should be directed to the individual publisher as copyright holder. 


\title{
Blazing and grazing: influences of fire and bison on tallgrass prairie stream water quality
}

\author{
Danelle M. Larson ${ }^{1,3}$, Bartosz P. Grudzinski ${ }^{2,4}$, Walter K. Dodds ${ }^{1,5}$, \\ Melinda D. Daniels ${ }^{2,6}$, Adam Skibbe ${ }^{1,7}$, AND Anthony Joern ${ }^{1,8}$ \\ ${ }^{1}$ Kansas State University, Division of Biology, 104 Ackert Hall, Manhattan, Kansas 66506 USA \\ ${ }^{2}$ Kansas State University, Department of Geography, 118 Seaton Hall, Manhattan, Kansas 66506 USA
}

\begin{abstract}
Fire and grazers (such as Bison bison) were historically among the most important agents for maintaining and managing tallgrass prairie, but we know little about their influences on water-quality dynamics in streams. We analyzed 2 y of data on total suspended solids (TSS), total N (TN), and total P (TP) (3 samples per week per stream during flow) in 3 prairie streams with fire and bison grazing treatments at Konza Prairie Biological Station, Kansas (USA), to assess whether fire and bison increase the concentrations of these water-quality variables. We quantified the spatial and temporal locations of bison $(\sim 0.21$ animal units $/$ ha) with Global Positioning System collars and documented bison trails, paw patches, wallows, and naturally exposed sediment patches within riparian buffers. Three weeks post-fire, TN and TP decreased ( $t$-test, $p<0.001$ ), but TSS did not change. Bison spent $<6 \%$ of their time within $10 \mathrm{~m}$ of the streams, increased the amount of exposed sediment in the riparian areas, and avoided wooded mainstem branches of stream $\left(\chi^{2}\right.$ test, $\left.p<0.001\right)$. Temporal trends suggest that low discharge or increased bison density in the stream may increase TSS and TP during the summer months. Our results indicate a weak connection between TSS and nutrients with bison access to streams over our 2-y study and indicate that low TSS and nutrients characterize tallgrass prairie streams with fire and moderate bison densities relative to surrounding land uses.
\end{abstract}

Key words: tallgrass prairie, grasslands, streams, burning, Bison bison, Bos bison, prescribed fire, grazers, total nitrogen, total phosphorus, total suspended solids.

The tallgrass prairie ecosystem possesses historical and intimate connections with fire and bison (Bison bison), so both should be studied when considering drivers of prairie stream ecosystem properties. Grasslands worldwide have coevolved with herbivores. In the Great Plains region of the USA, prairies have most recently evolved with Bison bison, the North American Bison (Stebbins 1981). Bison herds of 10-60 million were recorded by early settlers in the Great Plains, but by 1830 the species was near extinction because of hunting (Flores 1991, Shaw and Lee 1997). Strong firegrazing interactions in grasslands result in shifting mosaics of vegetation structure and quality through a series of recursive feedbacks (Fuhlendorf et al. 2009,

\footnotetext{
${ }^{3}$ E-mail addresses: daneller@ksu.edu

4 gobhawks@ksu.edu

5 wkdodds@ksu.edu

6 mddaniel@ksu.edu

7 askibbe@ksu.edu

8 ajoern@ksu.edu
}

Allred et al. 2011a), but how these feedbacks influence aquatic ecosystems is not well understood.

Prairies in regions with sufficient moisture to support trees are maintained as grasslands by a regular fire disturbance regime that enables grasses to thrive and eliminates or reduces woody plants (Stewart 1951). Surprisingly little research has been dedicated to fire effects on tallgrass prairie streams despite a recurrence interval of 1 to 10 y (Abrams 1985). Fire can decrease soil water-infiltration capacity and remove ground cover, which can lead to increased overland flow and soil erosion. In highrelief forested ecosystems, debris flows and high sedimentation have occurred following wildfire (Meyer et al. 2001, Moody and Martin 2001, Smith et al. 2010). Nevertheless, a study at Konza Prairie in Kansas (USA) suggested that burning did not significantly increase sediment loss or overland flow on the landscape (Duell 1990). Dodds et al. (1996) found that total $\mathrm{N}(\mathrm{TN})$ and $\mathrm{NO}_{3}{ }^{-}$concentrations in the water column increased as a function of number 
of days and years after fire in tallgrass prairie. However, they also found that $\mathrm{N}$ transport was related primarily to stream discharge. We are aware of only one study of stream sediment dynamics following fire in tallgrass prairie (Larson et al. 2013), and the nutrient trends in the literature are still unclear. After a prairie burn, large ungulates increase their time spent in burned areas (Daubenmire 1968, Vermeire et al. 2004). Thus, the presence of bison on burned ground could lead to interactive effects of fire and grazing on water quality.

Bison may affect water quality by their movement across the landscape and within creeks. Streams can be natural pathways for animal movement (Butler 1995). Animals tend to avoid traversing steep slopes and prefer to travel on gradually sloping terrain (Bruggeman et al. 2008), such as near flood plains and valley bottoms. Bison create well established stream crossing trails that can alter habitat by widening the channel and increasing the silt fraction of substrates, especially during storm flows (Butler 1995, Fritz et al. 1999). Trampling through streams could lead to sediment and nutrient suspension.

Other bison behaviors-grazing, foraging, wallowing, and pawing (a term that refers to intentional soil disturbance with hooves) - may affect water quality if the effects of these activities are functionally connected to streams by hillslope transport pathways. These bison behaviors increase bare ground and potential for sediment delivery to stream channels (Kondolf 1993, Greenwood and McKenzie 2001). Bison wallow regularly for many reasons, including shedding, rutting, group unity, itching, removing ectoparasites, and thermoregulation (McMillan et al. 2000). Wallowing can create patches of bare and compacted soil susceptible to erosion. Bison urinate in the wallows for either rutting or group cohesion, and this behavior could increase $\mathrm{NH}_{4}^{+}$and $\mathrm{TN}$ in the wallows and streams. Bison also paw large patches of soil adjacent to stream banks, perhaps to obtain minerals. All of these actions could increase sediment and nutrient input into streams.

Despite our increasing knowledge of the importance of fire and grazing in terrestrial grassland ecology (Knapp 1998, van Langevelde et al. 2003, Archibald et al. 2005), little research has been done to investigate the influence, including sediment and nutrient export dynamics, of fire and bison on prairie streams. Thus, the primary objectives of our study were to assess whether relationships exist among tallgrass prairie stream concentrations of total suspended solids (TSS), total $\mathrm{N}$ (TN), and total $\mathrm{P}$ (TP) and prairie burning, bison grazing, and areal extent and type of bison effects near the stream from pawing, wallowing, and development of stream trail crossings. We quantified the proportion of time bison spent within watersheds and the riparian zone with data from Global Positioning System (GPS)-collared bison. We compared watersheds disturbed by bison and fire with reference watersheds and watersheds dominated by row-crop agriculture in this ecoregion.

\section{Methods}

\section{Stream descriptions}

We studied 3 headwater intermittent tallgrass prairie streams on Konza Prairie Biological Station (KPBS) in northeastern Kansas, USA (lat 39 $5^{\prime} 55.65^{\prime \prime} \mathrm{N}$, long $96^{\circ} 36^{\prime} 19.91^{\prime \prime} \mathrm{W}$; Fig. 1). The KPBS is a large tract of unplowed, native tallgrass prairie (3497 ha) that is owned by the Nature Conservancy, managed by the Division of Biology at Kansas State University, and part of the Long-Term Ecological Research (LTER) network. Ivan soils (4051 Ivan Silt Loam) dominate floodplains and are characterized as deep and moderately well drained with numerous rock fragments (Oviatt 1998). The stream substrate consists mostly of limestone and shale rock fragments, and limestone bedrock is exposed in short segments of the streams.

We acknowledge that our study lacks replication at the watershed scale and includes pseudoreplicated water samples. We were able to monitor only 2 bisongrazed watersheds and 1 control (no bison grazing) watershed because of the rarity of headwater streams grazed by bison (and without other conflicting upstream land uses, such as row-crop agriculture). Furthermore, all of the watersheds have been under different burn regimes for the last 15 y. All 3 study streams (Shane, N2B, and N4D) are characterized by native tallgrass prairie uplands and discontinuous riparian gallery forests with minimal human influence other than prescribed fire and bison management that mimics historical tallgrass prairie conditions (Knapp 1998). Shane Creek was ungrazed, whereas bison have grazed at Kings Creek (subwatersheds N4D and N2B) since May 1992 at $\sim 0.21$ animal units $(\mathrm{AU}) / \mathrm{ha}$. Bison graze freely among watersheds $\mathrm{N} 2 \mathrm{~B}$ and N4D and several other surrounding watersheds year round and are minimally managed (i.e., no supplemental water and only rarely winter fed). Prairie burning in these watersheds occurs in March or April at different fire intervals. The Shane Creek watershed is burned annually, whereas N2B and N4D have target burn intervals of 2 and $4 \mathrm{y}$, respectively. Watersheds N2B and N4D were last burned in April 2009 (before water collections), and the Shane Creek watershed was burned in 2010 (during water collections) (Table 1). 


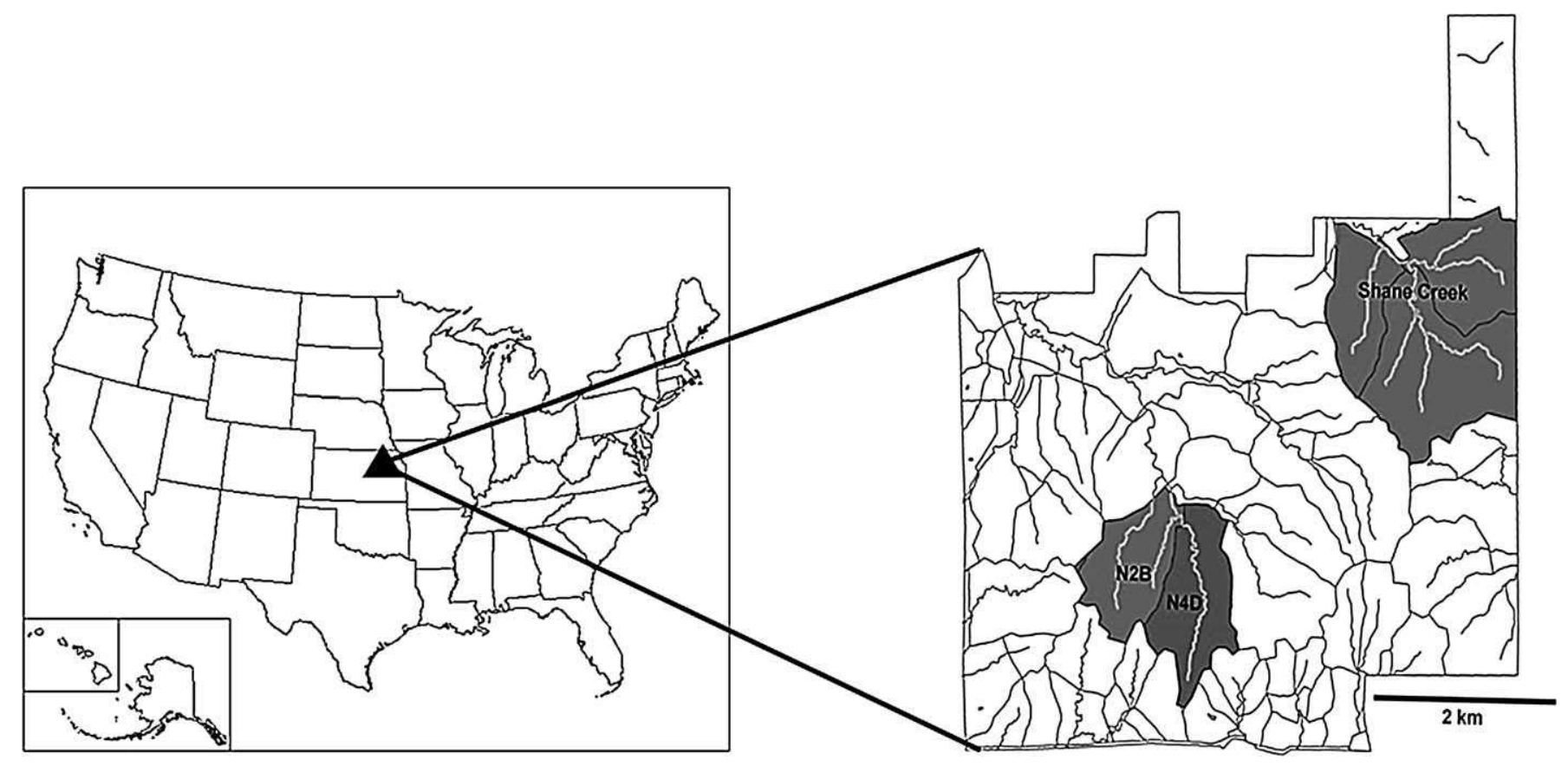

FIG. 1. Map of Konza Prairie Biological Station (KPBS), Kansas (USA), and the 3 studied watersheds (lat $39^{\circ} 5^{\prime} 55.65^{\prime} \mathrm{N}$, long $\left.96^{\circ} 36^{\prime} 19.91^{\prime} \mathrm{W}\right)$. N2B and N4D contain bison with unrestricted access between watersheds, whereas Shane Creek is ungrazed.

We manually delineated and measured watershed attributes, such as watershed area, longitudinal stream slope, stream sinuosity, floodplain area, and floodplain slope (Table 1) in ArcGIS (version 9.3; Environmental Systems Research Institute, Redlands, California). We digitized streams from a 2-m digital elevation model (DEM) based on the curvature of the stream morphology from the point of water sampling to the point where the streams terminated into hillslope. We calculated longitudinal stream slope as the difference between the high and low points of the streams divided by their length, and we calculated sinuosity as the length of the streams divided by the straight-line lengths. We digitized floodplain areas from the DEM as the flat area adjacent to the stream channel. We used the slope tool in ArcGIS to calculate the average floodplain slope. We used an interactive supervised classification method in ArcGIS to quantify woody riparian vegetation. We compiled discharge data $(Q)$ for N2B only. We measured $Q$ at

TABLE 1. Summary of the watershed characteristics and management at Konza Prairie, Kansas. The exposed sediments and \% contribution of sediments were quantified in a 10-m buffer from the stream and standardized by stream length. Values with different superscripts were significantly different among streams ( $\chi^{2}$ test, $\alpha / 3=0.017$ ).

\begin{tabular}{|c|c|c|c|}
\hline \multirow[b]{2}{*}{ Characteristics } & \multicolumn{3}{|c|}{ Watershed } \\
\hline & N2B & N4D & Shane \\
\hline Area (ha) & 78 & 119 & 415 \\
\hline Bison grazing (year round; $\sim 0.21$ animal units $/ \mathrm{ha}$ ) & Yes & Yes & No \\
\hline Burn interval (y) & 2 & 4 & 1 \\
\hline Average floodplain slope $(\%)$ & 7.5 & 8.0 & 8.6 \\
\hline Longitudinal slope $(\%)$ & 0.02 & 0.02 & 0.02 \\
\hline Floodplain area $\left(\mathrm{m}^{2} / \mathrm{m}\right.$ stream $)$ & $65^{\mathrm{a}}$ & $46^{\mathrm{b}}$ & $101^{\mathrm{c}}$ \\
\hline Average daily discharge $\left(\mathrm{m}^{3} / \mathrm{s}\right)$ & 0.009 & & \\
\hline Sinuosity ratio & 1.6 & 1.4 & 1.4 \\
\hline Exposed sediments $\left(\mathrm{m}^{2} / \mathrm{m}\right)$ & 0.183 & 0.156 & \\
\hline Contribution of bison wallows to exposed sediment (\% area) & 12 & 7 & \\
\hline Contribution of bison pawing to exposed sediment ( $\%$ area) & 12 & 28 & \\
\hline $\begin{array}{l}\text { Contribution of naturally bare banks to exposed } \\
\text { sediment (\% area) }\end{array}$ & 76 & 65 & \\
\hline
\end{tabular}


5-min intervals at a triangular throated flume. The stage height provided mean, maximum, and minimum daily $\mathrm{Q}$ (raw data can be found at: http:/ / www. konza.ksu.edu).

\section{TSS}

Beginning May 2009 and ending September 2010, we collected TSS from each stream 2 to 3 times/wk when streams flowed. We took samples from the same location at the base of the watershed just above the weirs every sampling period. We sampled from the center of the channel in a location where water was $\geq 10 \mathrm{~cm}$ deep with care not to disturb benthic sediments at or upstream from the sampling location. If bison were in the water upstream of the sampling site at the time of sampling, we noted their presence. We also documented stormflow conditions, defined as an increase in $\mathrm{Q}$ (of any magnitude) following a precipitation event. We analyzed and calculated TSS, volatile suspended solids (VSS), and total inorganic solids (TIS) according to ESS Method 340.2 (USEPA 1997). We also dried and weighed filters a $2^{\text {nd }}$ time to ensure that hydration did not confound results. Rewetting and redrying of multiple samples yielded $<1 \%$ change in the measured mass, so this procedure was discontinued after the first few months of sampling.

\section{Nutrients}

We collected water samples for nutrient analyses from the same locations as TSS in acid-washed bottles 3 times weekly from May 2009 to September 2010. We stored samples at $-30^{\circ} \mathrm{C}$ until analysis. We analyzed unfiltered stream water for total $\mathrm{N}$ (TN) and total P (TP) concentrations by a persulfate oxidation method (Ameel et al. 1993) in triplicate with an OI-Analytical Flow Solution IV autoanalyzer (O.I. Corporation, College Station, Texas) and averaged values.

\section{Exposed sediment patches}

We quantified the areas and slopes of all exposed sediment patches within $10 \mathrm{~m}$ of the stream channel to account for differences in potential sediment delivery to the bison-accessible streams N2B and N4D. Both watersheds were walked from the point of water sampling to the point upstream where the visible channel terminated to hillslope once in 2010. Exposed sediment patches within $10 \mathrm{~m}$ of the channel (i.e., riparian zone) were grouped into 3 source categories: 1) bison-pawed patches, 2) bison wallows, and 3) natural bare banks (Fig. 2A-C). Wallows and paw patches are bison-caused exposed patches and have distinct identifying features. Wallows are circular depressions on low-sloped terrain, and paw patches are typically on benches, have a distinct break in slope with the stream bank, have hoof markings, and are connected to bison trails. Naturally bare banks are defined as exposed patches above bankfull and cut banks that are in-stream exposures from water erosion. Bare banks are likely to be natural and not bison induced, but heavy trampling may increase the number and area of bare-bank patches. The criterion we used for measurement was $\geq 0.6 \times 0.6-\mathrm{m}$ area with $<40 \%$ cover by stabilizing vegetation or large rock. We marked patch locations via GPS and measured area and slope for each exposed sediment patch with survey tape and a digital level. We counted the number of bison crossings at N2B and N4D and marked their locations using GPS. The crossings were separated into mainstem (a $3^{\text {rd }}$-order stream section) and tributaries $\left(<3^{\text {rd }}\right.$-order stream sections).

Fire

We continued triweekly sampling of TSS and nutrients before and after a prescribed fire at Shane Creek on 3 March 2010. We used rainfall data obtained from a rain gauge stationed at the headquarters of KPBS to assess whether rainfall occurred within the 3 wk after prescribed burns (raw data available at: http://www.konza.ksu.edu).

\section{Bison locations}

Between 2008 and 2010, the Konza bison herd averaged $380 \pm 31$ before cull and decreased to $290 \pm$ 19 individuals after cull in early November. We chose a $3 \%$ subset of matriarchal females for year-round tracking via Telonics ${ }^{\circledR}$ GPS collars (accuracy $=\sim 4 \mathrm{~m}$; Telonics, Mesa, Arizona) set to record data at 2-h intervals. We mapped and analyzed bison location data in ArcGIS to identify the overall density and frequency of bison within $10 \mathrm{~m}$ of the streams in both bison watersheds and to describe temporal dynamics of riparian use by the bison. We normalized data for area within each watershed.

\section{Statistical analyses}

Statistical analyses were run in SAS (version 9.1.3; SAS Institute Inc., Cary, North Carolina) and R (version 2.1.3; R Development Core Team, Vienna, Austria), with additional use of the $\mathrm{R}$ packages: vegan (Oksanen et al. 2011), BiodiversityR (Kindt and Coe 2005), car (Fox and Weisberg 2011), coin (Hothorn et al. 2006), and labdsv (Roberts 2010). All statistical 

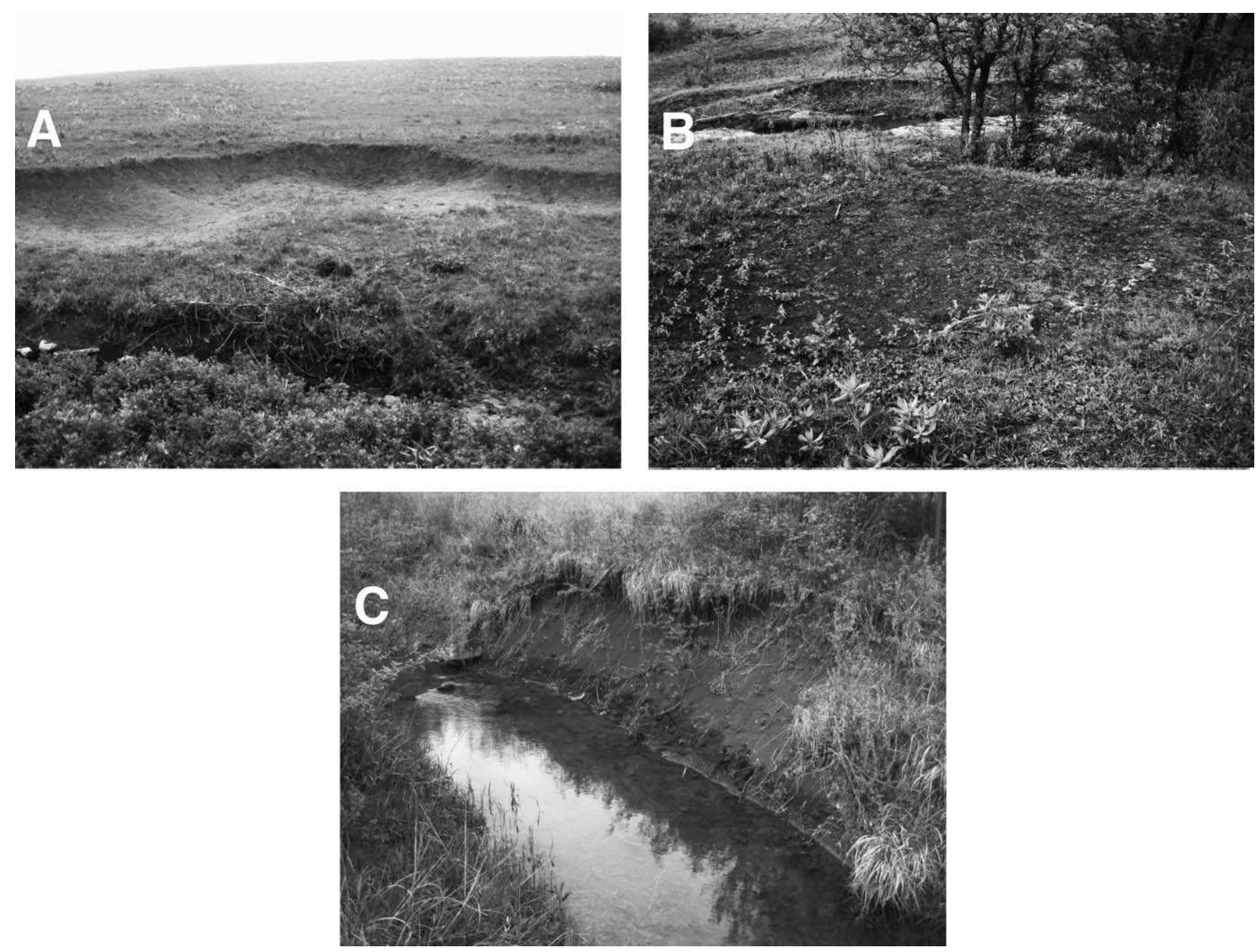

FIG. 2. Photographs showing a large paw patch from bison (A), a bison wallow near a stream (B), and a natural exposed sediment patch (C). Photographs are from Konza Prairie Biological Station, Kansas.

outliers ( $n=6$; defined as $\geq 3$ standard deviations from the mean) arose during storm flow or when bison were in the stream while we were sampling. We removed the outliers and repeated the analyses, but trends were consistent between analyses with and without outliers (data not shown), so we report results with outliers included to provide the most conservative estimates. We report median sediment and nutrient concentrations because rare events (such as storms and bison in the streams while sampling) had a disproportionate effect on the mean.

The TSS data violated assumptions of normality and equal variances, so we analyzed them with nonparametric tests. In an analysis of temporal autocorrelation, we found no statistical correlation after $4 \mathrm{wk}$, so we blocked data by month (roughly $4 \mathrm{wk}$ ). We used Friedman's Test (nonparametric analysis of variance with repeated measures with data blocked by month) followed by a post-hoc Mann-Whitney $U$ test with
Bonferroni correction to test whether TSS, TIS, VSS, and VSS:TIS varied among the 3 watersheds (2 grazed, 1 ungrazed). We pooled data from all streams and used Kendall's $\tau$ rank correlation to assess whether TSS, VSS, TIS, and VSS:TIS were correlated with nutrients, discharge, rainfall, stormflow events, or bison presence in the stream during sampling. We used MannWhitney $U$ tests to assess whether TSS increased in the $3 \mathrm{wk}$ post-fire (after $3 \mathrm{wk}$, regrowth of grasses covers the bare soil) and whether the areas and slopes of the exposed sediments (natural and bison-induced) differed among watersheds.

Nutrient values required $\log (x)$-transformation to meet normality assumptions. We used 1-way analysis of variance (ANOVA) and post hoc Least Squares Differences (LSD) to test for differences in nutrient concentrations among streams. We used Student's $t$ tests to evaluate whether fire altered nutrient concentrations. 
TABLE 2. Median suspended solids and nutrient concentrations at 3 streams on Konza Prairie, Kansas. We examined total suspended solids (TSS), total volatile solids (VSS), total inorganic solids (TIS), total N (TN), and total P (TP) to determine effects of bison presence and prescribed fire. Values with different superscript letters are significantly different among streams (MannWhitney $U$ test, $\alpha / 3=0.017)$. * indicates that nutrient values were significantly lower after than before a prescribed burn $(t$-test, $\alpha$ $=0.05)$.

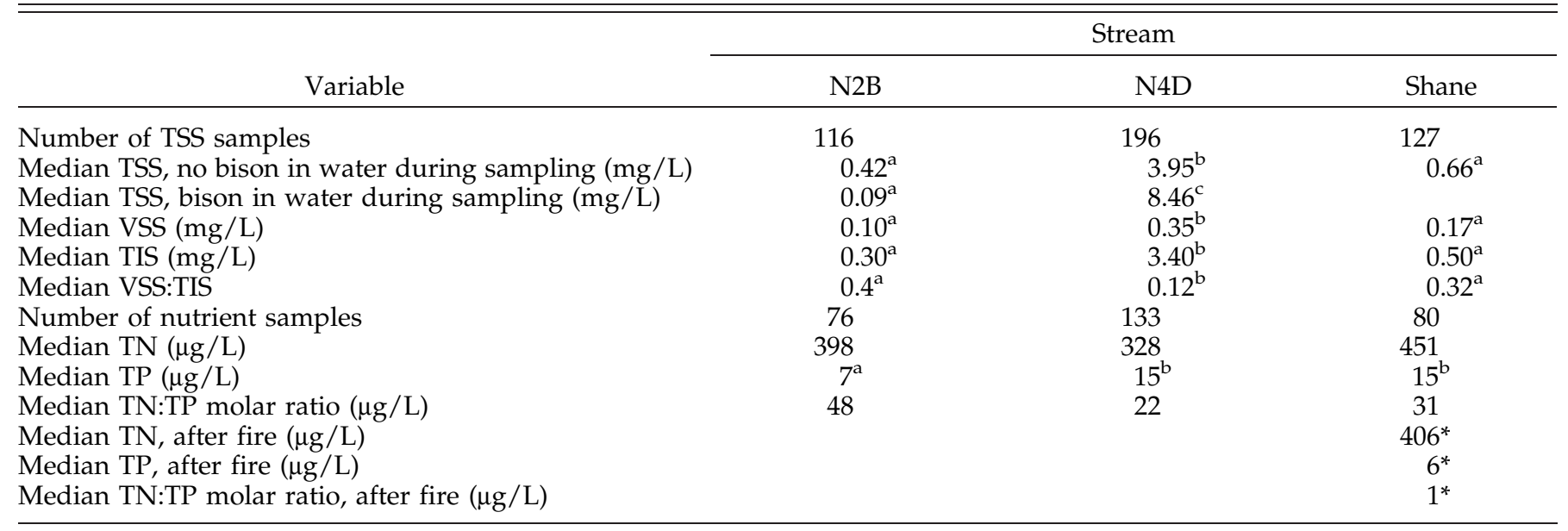

We used a $\chi^{2}$ goodness-of-fit test to compare the amount of time bison were present in the tributaries vs mainstem branches and riparian vs upland locations between the 2 grazed watersheds. We also used a $\chi^{2}$ goodness-of-fit test to indicate which watershed characteristics (e.g., floodplain slope; Table 1) differed between watersheds.

We used principal component analysis (PCA) to illustrate the relationships among the response variables and to assess the similarities and differences among the 3 streams. We used TSS, VSS:TIS, TN, TP, and the TN:TP molar ratio as response variables. We also used a multiple linear regression with $\log (x)$ transformation to determine if stormflow, bison presence in the stream during sampling, and fire explained significant amounts of variation in TSS, TN, and TP.

\section{Results}

\section{Total suspended solids}

TSS differed significantly among the streams $\left(\chi^{2}\right.$ 2df $=204.05, p<0.001$; Table 2, Fig. 3A), but not between grazed and ungrazed watersheds (mean rank by watershed $=340$ for N4D, 172 for Shane [ungrazed], and 106 for N2B). Median TSS values were $10 \times$ greater at N4D than at the other 2 streams (Fig. 3A). These differences among the streams were consistent for VSS $\left(\chi_{2 \mathrm{df}}^{2}=145.67, p<0.001\right)$, TIS $\left(\chi_{2 \mathrm{df}}^{2}=240.87\right.$, $p<0.001)$, and VSS:TIS $\left(\chi_{2 \mathrm{df}}^{2}=200.45, p<0.001\right)$. TSS concentration increased $10 \times$ at N4D during July to November when the other streams were dry (Fig. 4AC). We removed the TSS data for the dry months and reran Friedman's test to assess whether TSS differed among streams during the months with flow and still detected a $\sim 10 \times$ difference at N4D $\left(\chi_{2 \mathrm{df}}^{2}=226.38\right.$, $p<0.001)$. However, TSS was generally $5 \times$ greater when bison were in the stream during sampling $(\tau=$ $0.137, p=0.003$; Table 2). For the linear model, TSS $\approx$ Stormflow + BisonPresence + Fire, the variables Stormflow $\left(\beta=3.65, t_{471}=8.736, p<0.001\right)$ and BisonPresence $\left(\beta=0.93, t_{471}=3.125, p=0.002\right)$ were significant predictors, but Fire was not. The total amount of variance explained by this model was $17.5 \%$.

At N2B, daily mean $\mathrm{Q}$ was positively correlated with TSS $(\tau=0.146, p=0.02)$, VSS $(\tau=0.150, p=$ $0.02)$, and TIS ( $\tau=0.1523, p=0.01)$, but not VSS:TIS $(\tau=0.105, p=0.19)$. TSS was positively correlated with small rainfall events $<24 \mathrm{~mm} / \mathrm{d}(\tau=0.194, p<$ 0.001 ) and larger stormflow rain events $>24 \mathrm{~mm} / \mathrm{d}$ $(\tau=0.167, p<0.001)$. $Q$ was correlated with month $(\tau=0.254, p=0.006)$ and increased from January until July. This increase corresponded to an increasing trend in TSS (Fig. 4A-C). N2B and Shane Creek had no flow from July to October 2009.

\section{Nutrients}

TP concentrations did not differ between N4D and Shane $(p=0.999)$, but TP in both was higher than in N2B ( $p<0.001$; Table 2, Fig. 3B). TN concentrations did not differ among streams $(p=0.104$; median $=$ $392 \mu \mathrm{g} / \mathrm{L}$; Table 2, Fig. 3C). Bison presence in the stream during sampling did not influence TN or TP $(p$ $=0.574)$. Storm flows increased TN $12 \times(p=0.015)$ 

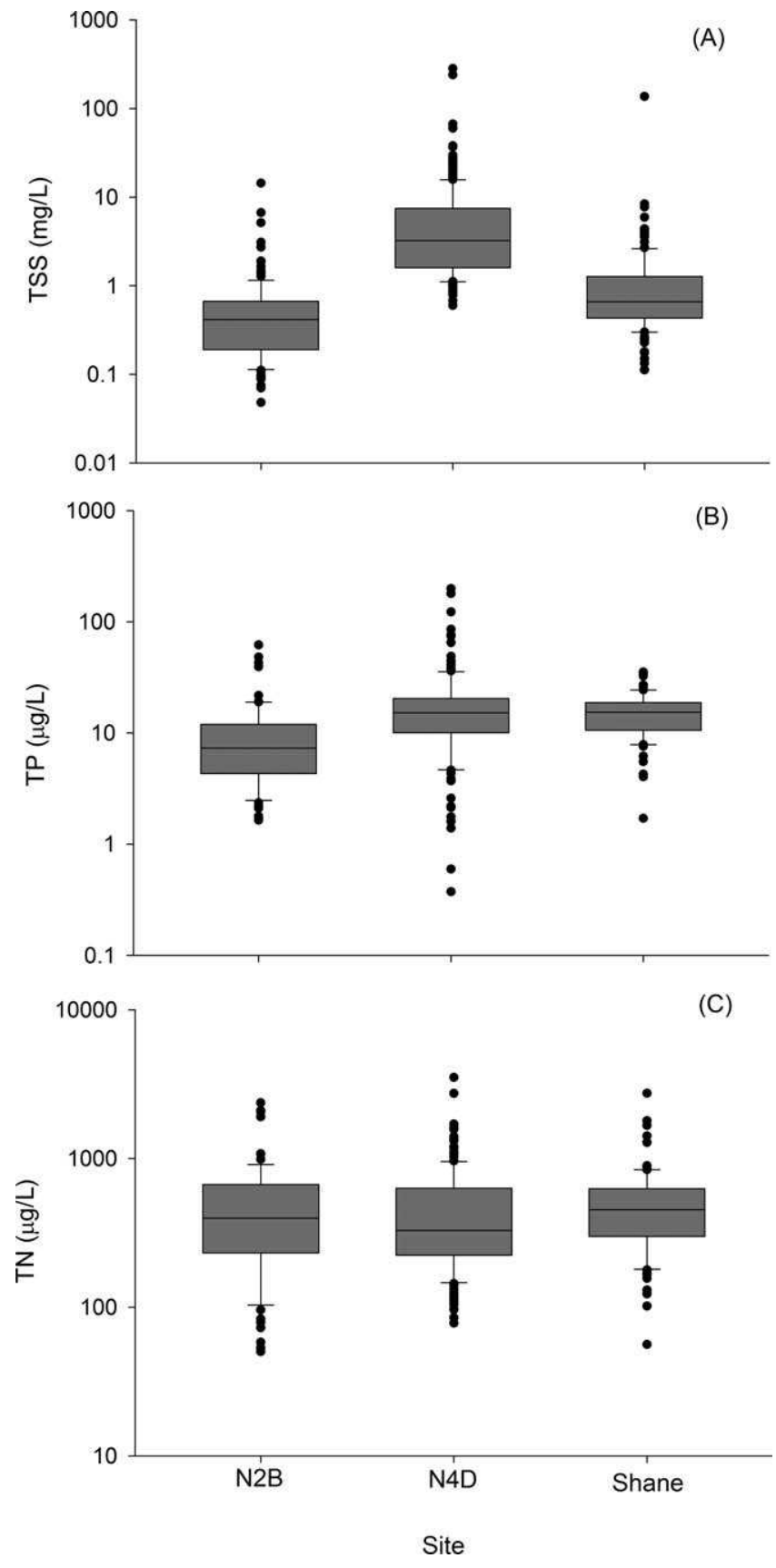

FIG. 3. Box plots (on log-scale) of total suspended solids (TSS) (A), total P (TP) (B), and total N (TN) (C) for 3 watersheds at Konza Prairie Biological Station, Kansas. Samples were taken 3 times weekly when streams were flowing from May 2009 through Sept 2010. Lines in boxes are medians, box ends are quartiles, whiskers show $95 \%$ confidence intervals, and dots show statistical outliers.

and TP $3 \times(p=0.003)$ and decreased TN:TP $4 \times(p=$ $0.004)$. TSS was positively correlated with $\mathrm{TN}(\tau=$ $0.133, p=0.036)$ and TP $(\tau=0.301, p<0.001$; Fig. 5). TN:TP was inversely correlated with TSS $(\tau=-0.201$, $p<0.001$; Fig. 5). TP and TN:TP were greater in

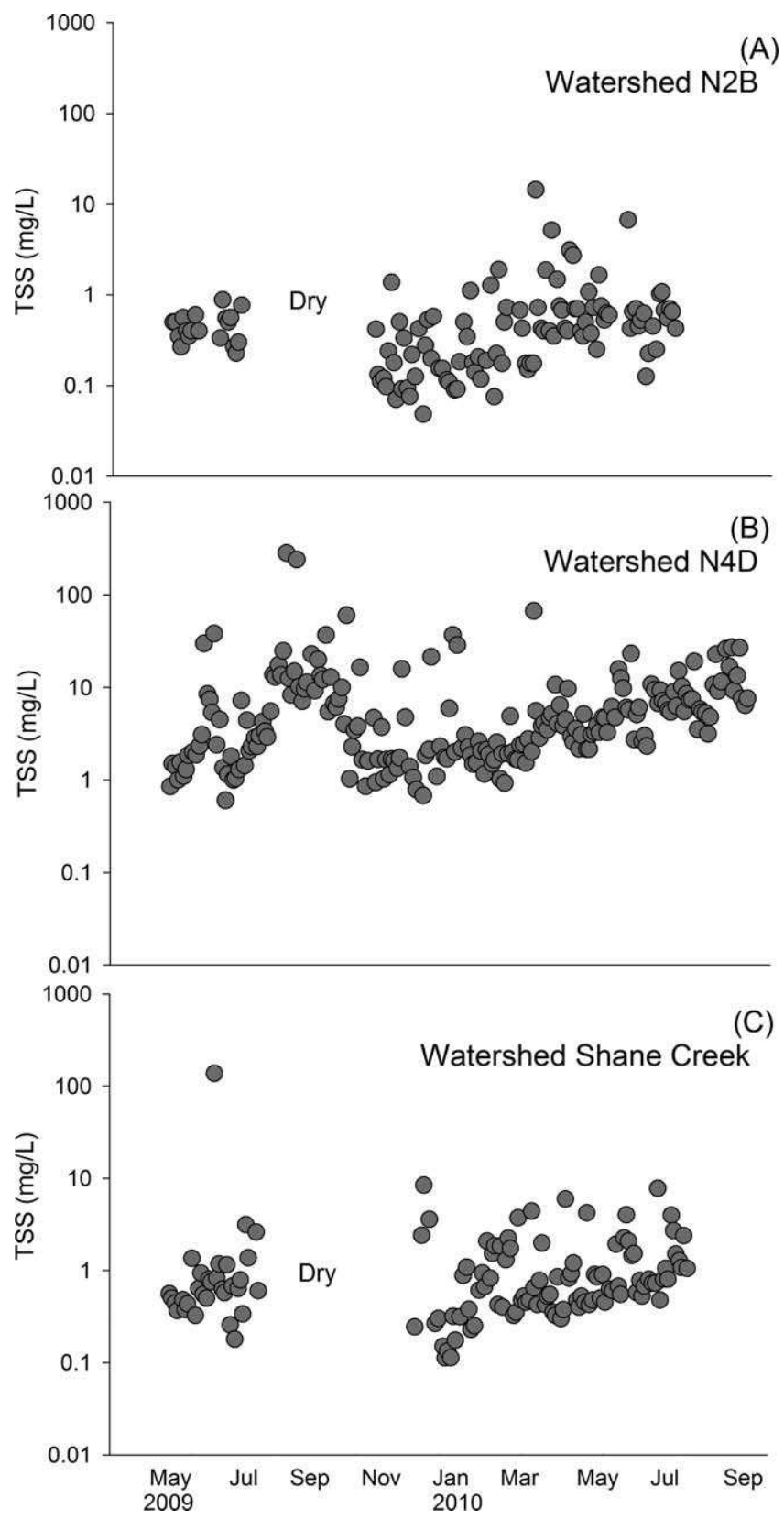

FIG. 4. Temporal trends in total suspended solids (TSS) for stream N2B (A), N4D (B), and Shane's Creek (C) on Konza Prairie. The intermittent streams N2B and Shane were dry from July to November 2009, whereas TSS increased $>10 \times$ at N4D (note the log scale). TSS did not increase during the $3 \mathrm{wk}$ after a prescribed prairie burn at Shane Creek in March 2010.

winter (November-January) than in other seasons ( $p$ $=0.004$ and $p=0.002$, respectively). At N4D, TP was marginally greater in summer (July-October) than in other seasons $(p=0.067)$. None of the variables in the linear regression model, $\mathrm{TN} \approx$ Stormflow + BisonPresence + Fire, was a significant predictor of TN, and 


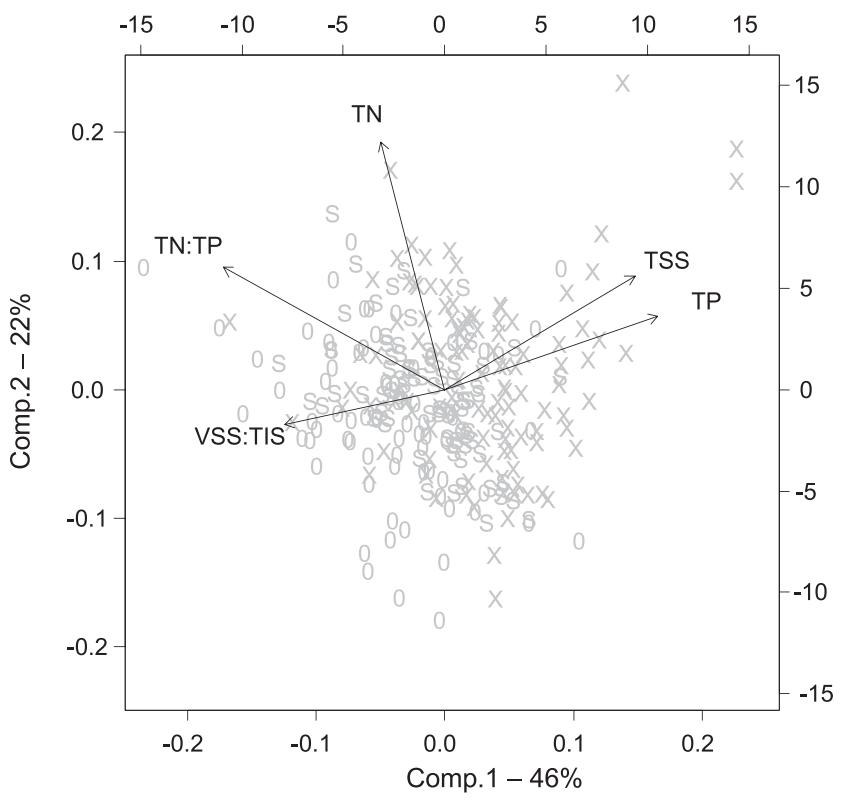

FIG. 5. A principal component analysis biplot showing the relationship among 5 measured water-quality variables, all which are $\log (x)$-transformed. Comp $=$ component, $\mathrm{TN}$ $=$ total $\mathrm{N}, \mathrm{TP}=$ total $\mathrm{P}, \mathrm{TN}: \mathrm{TP}=\mathrm{TN}: \mathrm{TP}$ molar ratio, $\mathrm{TSS}=$ total suspended solids, and VSS:TIS = VSS:TIS ratio. The data are from 3 streams at Konza Prairie, Kansas. The points are coded by watershed: $0=\mathrm{N} 2 \mathrm{~B}, \mathrm{X}=\mathrm{N} 4 \mathrm{D}$, and $\mathrm{S}=$ Shane Creek.

the model explained only $1.2 \%$ of the variance. The linear regression model, $\mathrm{TP} \approx$ Stormflow + BisonPresence + Fire explained $11 \%$ of the variance, and Stormflow significantly increased TP $\left(\beta=2.64, t_{471}=\right.$ 61.004, $p<0.001)$, whereas Fire significantly decreased TP $\left(\beta=-0.52, t_{471}=-2.419, p=0.016\right)$.

\section{Exposed sediment patches}

In comparisons of exposed sediment characteristics between the bison-grazed watersheds (N4D and N2B), all values are reported as standardized by stream length. The total amount of exposed sediment was similar between watersheds (N2B: $0.183 \mathrm{~m}^{2} / \mathrm{m}, \mathrm{N} 4 \mathrm{D}$ : $0.156 \mathrm{~m}^{2} / \mathrm{m}$; Table 1). The slopes of all types of exposed patches did not differ in either watershed $(U=3693$, $p=0.675)$, had a median of $32^{\circ}$, and ranged from $4^{\circ}$ to $85^{\circ}$. For both watersheds, $\geq 1 / 2$ of the total exposed sediment area was contributed by bare banks (Table 1 ). We analyzed the total amount of exposed sediment from $200 \mathrm{~m}$ upstream of the water sampling locations to determine if high sediment exposure resulted in high TSS in N4D (N2B: $254 \mathrm{~m}^{2}$, N4D: $117 \mathrm{~m}^{2}$ ). Thus, the amounts of exposed sediment near the sampling source and throughout the watershed were not driving the $10 \times$ difference in TSS between these streams.
The areas of wallows and pawed patches (bisoninduced exposed sediments) did not differ from the area of bare banks ( $p=0.184)$ because many barebank areas were small and some pawed patch areas were large (up to $80 \mathrm{~m}^{2}$ ). We counted 8 wallows and 32 paw patches within N4D's 10-m streamside buffer, and 10 wallows and 12 paw patches within N2B's 10-m streamside buffer. Watershed N2B had twice as much area of wallows (resulting from more wallows and larger wallow size) and half as much area from pawed patches (Table 1). At both streams, wallows were low-slope depressions $(-2 \pm 1.5 \%$ [SD] $)$ and the distance averaged $6 \mathrm{~m} \pm 5 \mathrm{~m}$ ) from the stream bank.

Fire

TSS concentrations did not increase during the $3 \mathrm{wk}$ after a prescribed prairie burn at Shane Creek in March $2010(U=623, p=0.901)$. A total of $51 \mathrm{~mm}$ of rain fell from the start of the burn (which exposes soil) to $3 \mathrm{wk}$ later (assuming grass reestablishment). Two rain events $>14 \mathrm{~mm}$ occurred on $1 \mathrm{~d}$. The fire reduced TN by $50 \%$ and TP by $200 \%(p<0.001)$, but the TN:TP molar ratio increased $(p<0.001) 17 \times$ because the effect of fire was greater on TP than on TN. The linear regression model, $\mathrm{TP} \approx$ Stormflow + BisonPresence + Fire also showed that Fire significantly decreased TP $\left(\beta=-0.52, t_{471}=-2.419, p=0.016\right)$. Despite the immediate consequence of burning, the burn intervals of 1,2 , and $4 \mathrm{y}$ did not substantially alter TSS concentrations. N4D had the highest TSS concentrations but the longest burn interval (4 y). Shane Creek had an annual burn interval, but low TSS and similar nutrient concentrations relative to the less frequently burned watersheds.

\section{Bison locations}

Bison were observed more frequently in the stream during sampling of N4D $(n=7)$ than of N2B $(n=1)$. Bison were observed in the stream during sampling immediately above the N4D sampling site during June, July, and August-a time during which sediment concentrations and TP spiked and the other bisonaccessible stream, N2B, was dry (Fig. 4A, B). This finding also corresponds with the GPS data, which showed that bison were observed $4 \times$ more often in N4D than N2B during these months (Table 3, Fig. 6). However, bison presence in the riparian buffer was $8 \times$ higher in December, January, and February than in other months (Fig. 6), a time when TSS concentrations were lowest and nutrients were highest.

Trends in the locations of GPS-collared bison were consistent across years sampled and between watersheds (Table 3). We standardized all GPS data by 


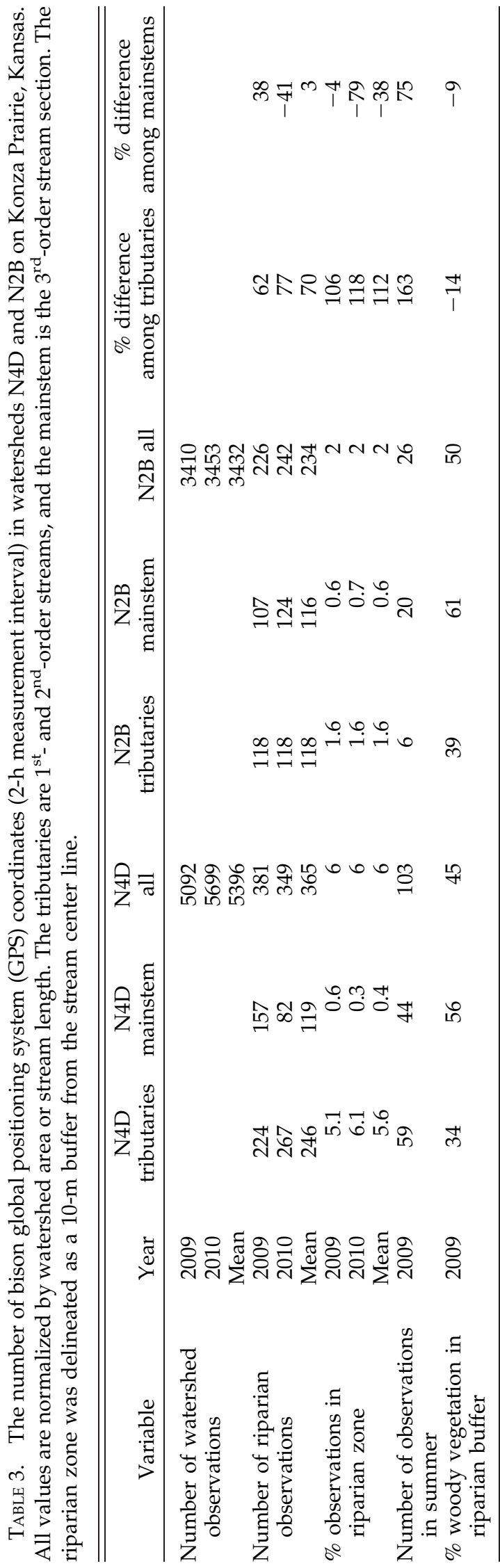

stream length. Bison were tracked more often in headwater tributary zones than the $3^{\text {rd }}$-order mainstem zones $(p<0.001)$. Bison spent a maximum of $6 \%$ of their time in the riparian zone and streams, and most of that time was spent in the riparian zones of tributaries $(p<0.001)$. In both years, bison spent nearly $2 \times$ as much time in N4D as in N2B $(p<0.001$; Fig. 7, Table 3). In both streams, $\sim 60 \%$ more wooded vegetation occurred at mainstem branches than at tributaries (Table 3). This difference may account for bison preference. The riparian zones in the bison watersheds make up 12 to $13 \%$ of the total watershed area, but bison spent only $6 \%$ of their time in the $10-\mathrm{m}$ riparian zone, a result that suggests they may be selecting against riparian areas. The density of bison trail crossings was $48 \%$ greater in N2B than N4D. The density of trails at $\mathrm{N} 2 \mathrm{~B}$ was 0.024 crossings $/ \mathrm{m}$ of stream length, compared to only 0.016 crossings $/ \mathrm{m}$ at N4D. A bison stream crossing was documented approximately every $41 \mathrm{~m}$ of stream length at N2B and every $67 \mathrm{~m}$ at N4D.

\section{Discussion}

Our observed effects and discussion points should be considered tentative because our study design could not include true replication at the primary scale of interest and may have contained confounding factors (i.e., burn regime and other unmeasured watershed-scale differences, such as geology). Fire regime differed in each watershed and potentially confounds the effects of fire and bison on waterquality variables. Pseudoreplication occurred when water was sampled 3 times weekly at the same streams because the water samples were not independent of one another. However, our analysis of temporal autocorrelation and subsequent data treatment (i.e., blocking) minimized effects to the F-ratio. The strength and unique aspect of our study (e.g., long-term water-quality monitoring in bison-grazed watersheds in remnant tallgrass prairie) also is its statistical shortcoming. Therefore, future studies will be required to assess further the effects of bison on water quality and of other managed ungulates like elk and cattle on the tallgrass prairie.

The effects of bison presence and prescribed prairie burning on suspended sediment and nutrient concentrations appeared minor in the KPBS study catchments. The small amount of time $(<6 \%)$ spent by bison in the streams could explain why their effect on TSS and nutrients was minimal. Bison did increase TSS while standing in the stream and increased bare soil by wallowing and pawing in riparian areas, but their presence in the watersheds did not increase 


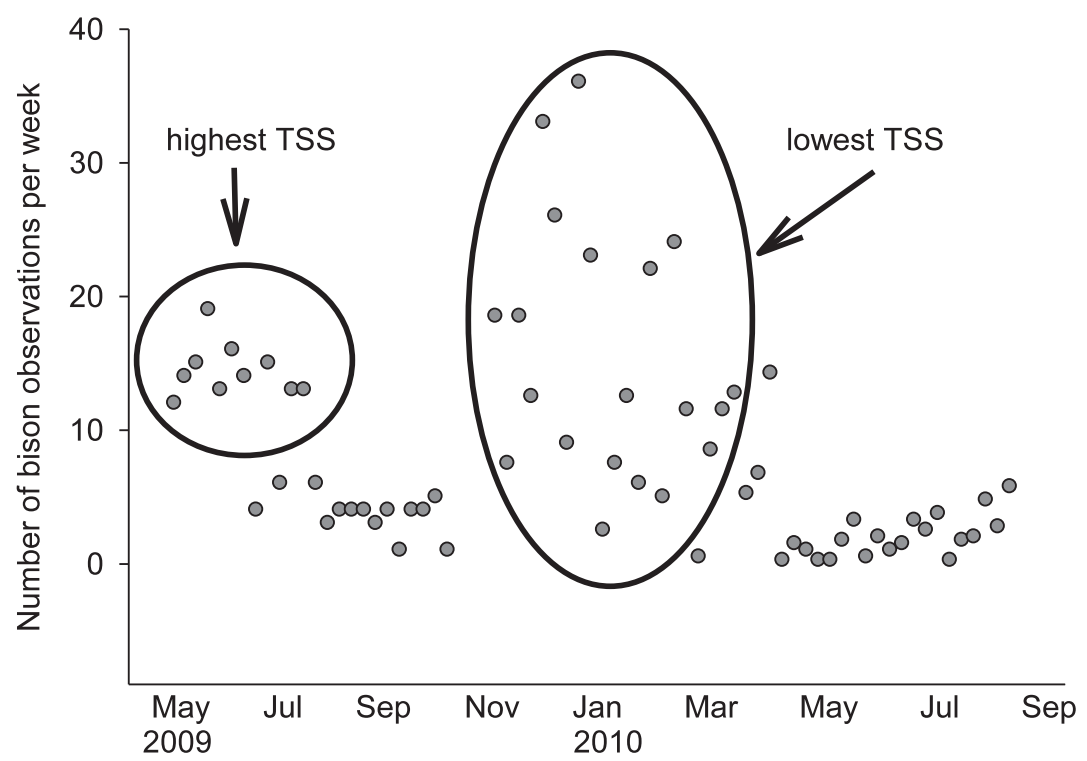

FIG. 6. Temporal trends in bison use of the riparian buffer (within $10 \mathrm{~m}$ of stream N4D) at Konza Prairie Biological Station, Kansas, from May 2009 through August 2010. Ovals indicate periods during which total suspended solids (TSS) were highest or lowest.

long-term sediment or nutrient concentrations when compared to an ungrazed watershed. The prescribed prairie burning did not have immediate effects on sediment nor did the yearly interval frequency of fire.

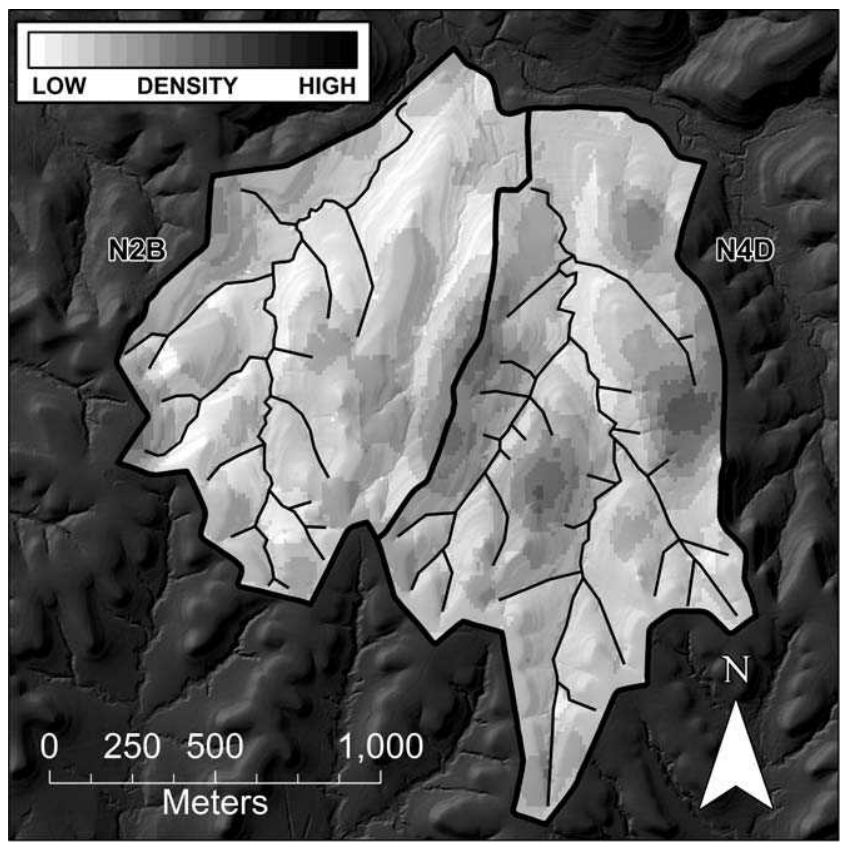

FIG. 7. A map of the relative density of bison in watersheds N2B and N4D at Konza Prairie Biological Station, Kansas in April 2009. Bison spent $2 \times$ as much time in N4D than in N2B. Darker patches indicate a greater density of bison.
The slight differences in nutrient concentrations among watersheds cannot be attributed clearly to bison, but burning did temporarily decrease nutrient levels.

We did not detect a direct effect of fire on TSS, but we did observe a significant decrease in nutrients. Prairie burning at Shane Creek and throughout the Great Plains typically occurs during early spring, a time when precipitation is greatest, and the potential for overland flow is high because of lack of vegetation. Above-ground biomass is completely burned during fires, but the roots still bind the soil because of stimulated root production (Johnson and Matchett 2001), making overland erosion unlikely on Konza Prairie (Oviatt 1998). During the 3 wk after fire when the soil was bare, relatively low amounts of precipitation $(<16 \mathrm{~mm} / \mathrm{d})$ occurred on 7 days. The prescribed fire at Shane Creek reduced TN 50\% and TP 200\%, a trend consistent with reductions observed after 2 other tallgrass prairie burns (Larson et al. 2013). Nutrient reduction might have been caused by algal growth and nutrient uptake in response to increased light availability after burning. We were able to document fire effects only in an ungrazed watershed, so future investigators should examine whether introduction of grazers shortly after fire (a common practice in tallgrass prairie) alters TSS concentrations in streams.

Multiple lines of evidence suggest that bison prefer certain watersheds and that these preferences may change over time. Our GPS and observational data 
show that bison spent more time in watershed N4D than N2B in 2009 and 2010. However, watershed N2B had $2 \times$ the density of stream crossings and $2 \times$ the wallow area found in N4D. These stream crossings and riparian wallows could be scars from past bison use and may not reflect present bison activity, or they might show that bison tend to use N2B to get from one preferred area to another. Bison move to watersheds after a fire, and fire occurred in both watersheds N2B and N4D in spring 2009. Bison preference for a watershed also might be associated with discharge or the availability of permanent water. Bison favored N4D, the watershed that had a greater average $Q$ and a supply of flowing water in summer.

Bison displayed affinity for nonwooded sections in upland tributaries. Bison seldom consume woody species (Knapp et al. 1999) and avoid wooded areas (Allred et al. 2011b). Our data showed that the bison spent a larger proportion of time in the smaller upland tributaries, which had less riparian woody cover (Table 3), than in the mainstems. Woody vegetation dominates the mainstem riparian zones of our study streams, and thick forest galleries surrounding the mainstem may hinder or deter access for bison. Avoidance of the wooded mainstems could be a result of lack of food, desire to be in windy areas to deter insects, or hindrance of animal movement.

How trends in animal density and seasonal patterns of grazing are connected to nutrient and sediment dynamics is not obvious. A seasonal $10 \times$ spike in TSS concentrations (Fig. 4A-C), an increase in TP, and a $4 \times$ increase in bison use at N4D compared to the dry N2B stream occurred during late summer and early autumn (Table 3). Thus, we can hypothesize that the bison had moved to N4D to have better access to water, resulting in the observed seasonal increase in TSS and TP concentrations in N4D. Bison require more water in summer than in other seasons because of increased metabolic activity and often shift from upland grazing to lowland grazing where plant productivity is greater (Knapp et al. 1999). In winter, bison eat snow to meet their water needs, a behavior that could limit the need to access streams. However, bison abundance in the riparian buffer and streamwater TP concentrations were highest in winter. Bison probably congregate in the lowlands in winter to shelter from cold and to obtain drinking water because snow is not prevalent at KPBS most years. Bison use of lowlands decreases in the summer and increases in the winter months (Fig. 6). If bison density affects waterquality variables, then sediment and nutrient concentrations could be seasonally influenced.

We monitored suspended sediment and nutrient export dynamics, but we were unable to detect potential local effects from fire and bison. Nutrient and sediment inputs may be limited to the site of impact and not the entire stream network. Headwaters often retain sediments and nutrients (Alexander et al. 2007), which could cause a failure to detect treatment differences based on our analyses of samples collected at a single station at the outlet of the watershed. Our analysis of total exposed sediment near the watersampling location suggests exposed sediment could not explain the $10 \times$ increase of TSS at N4D. However, moderate bison use of the stream near the sampling location (Fig. 7) could have influenced TSS concentrations. A previous study showed locally constrained effects of bison at stream crossings, which had lower macroinvertebrate richness and greater amounts of fine sediments compared to sites immediately upstream from the crossings (Fritz et al. 1999). Bison do heavily trample the permanent springs on KPBS when most of the ephemeral reaches are dry and export is not possible (data not shown). Bison and fire could have significant local consequences for the biological communities and geomorphology that we did not measure.

Cattle are often viewed as potential surrogates for bison in Great Plains grasslands. These large ungulates are closely related and feed differently than other large herbivores native to the ecosystem (e.g., deer are browsers). Cattle and bison enhance prairie vegetation diversity similarly (Collins et al. 1998) and facilitate soil nutrient cycling (Knapp et al. 1999). However, few studies have examined the in-stream effects of either species in tallgrass prairie. Bison and cattle differ in their water consumption and locations of grazing lawns. Cattle prefer lowland grazing and require more water than bison (Christopherson et al. 1979, Allred et al. 2011b), so their effects on streams may differ. Baseline reference data for effects of bison on sediment and nutrient concentrations are needed to make comparisons to effects of cattle. Bison and cattle stocking densities must be taken into account when comparing animal effects. Bison densities at KPBS are considered low to moderate density $(\sim 0.21 \mathrm{AU} / \mathrm{ha})$, whereas cattle densities in the Flint Hills region of Kansas are often $0.8 \mathrm{AU} /$ ha or greater (Derner et al. 2006). Continuous cattle grazing can cause substantial increases in sediment and nutrient loss in Kansas (Olness et al. 1975), and we presume these sediments and nutrients enter waterways. More research is needed to compare the impacts of bison vs cattle in prairie streams because current knowledge hints at important species differences.

The greatest sediment and nutrient values recorded in our study fall below current ranges for most streams across this ecoregion. TSS reference values do not exist for this area, but our values from KPBS 
watersheds that experience bison and fire (median: $\sim 2 \mathrm{mg}$ /L TSS) are 2 orders of magnitude lower than values in streams draining watersheds affected by row-crop agriculture (median: $\sim 200 \mathrm{mg} / \mathrm{L}$ TSS; Dodds and Whiles 2004). Smith et al. (2003) suggested reference nutrient ranges of 20 to $300 \mu \mathrm{g} / \mathrm{L}$ for TN and 7 to $75 \mu \mathrm{g} / \mathrm{L}$ for TP in the Great Plains/Shrublands ecoregion where our study took place. Our values (with bison and fire) fall within these ranges. Dodds et al. (2009) documented regional nutrient concentrations in streams influenced by humans $2 \times(\mathrm{TP})$ and $4 \times(\mathrm{TN})$ greater than values in our study. Our data indicate that bison and fire are not significant drivers of sediment and nutrient export in these tallgrass prairie streams. In all, the natural processes (i.e., fire and bison) occurring in tallgrass prairies do not hinder good streamwater quality.

\section{Acknowledgements}

We thank the National Science Foundation funded Konza Prairie Long-Term Ecological Research (LTER) research grant (NSF/DEB 1020485) and the Missouri Department of Conservation for funding. We thank Stacy Hutchinson, Rob Daniels, and Brandon Lantz for GIS assistance, the LTER field technicians and Amanda Kuhl for water sampling, and Rosemary Ramundo for sediment and nutrient analyses. Thanks go to James Whitney, Matthew Troia, and Keith Gido for help with statistical analysis and the Kansas State University Aquatic Journal Club for manuscript edits. This is publication 13-302-J from the Kansas Agricultural Experiment Station.

\section{Literature Cited}

Abrams, M. D. 1985. Fire history of oak gallery forests in a northeast Kansas tallgrass prairie. American Midland Naturalist 114:188-191.

Alexander, R. B., E. W. Boyer, R. A. Smith, G. E. Schwarz, AND R. B. MoORE. 2007. The role of headwater streams in downstream water quality. Journal of the American Water Resources Association 43:41-59.

Allred, B. W., S. D. Fuhlendorf, D. M. Engle, And D. Elmore. 2011a. Ungulate preference for burned patches reveals strength of fire-grazing interaction. Ecology and Evolution 1:132-144.

Allred, B. W., S. D. Fuhlendorf, and R. G. Hamilton. 2011b. The role of herbivores in Great Plains conservation: comparative ecology of bison and cattle. Ecosphere 2:art26.

Ameel, J. J., R. P. Axler, And C. J. Owen. 1993. Persulfate digestion for determination of total nitrogen and phosphorus in low-nutrient waters. American Environmental Laboratory 10:7-10.

Archibald, S., W. J. Bond, W. D. Stock, and D. H. K. FAIRBANKS. 2005. Shaping the landscape: fire-grazer interactions in an African savanna. Ecological Applications 15:96-109.

Bruggeman, J. E., R. A. Garrott, P. White, F. G. R. Watson, AND R. W. WALLEN. 2008. Effects of snow and landscape attributes on bison winter travel patterns and habitat use. Terrestrial Ecology 3:623-647.

ButLeR, D. R. 1995. Zoogeomorphology: animals as geomorphic agents. Cambridge University Press, Cambridge, UK.

Christopherson, R. J., R. J. Hudson, and M. K. ChristopherSON. 1979. Seasonal energy expenditures and thermoregulatory responses of bison and cattle. Canadian Journal of Animal Science 59:611-617.

Collins, S. L., A. K. Knapp, J. M. Briggs, J. M. Blair, and E. M. STEINAUER. 1998. Modulation of diversity by grazing and mowing in native tallgrass prairie. Science 280:745-747.

DaubenmiRe, R. 1968. Ecology of fire in grasslands. Advances in Ecological Research 5:209-266.

Derner, J. D., J. K. Detling, and M. F. Antolin. 2006. Are livestock weight gains affected by black-tailed prairie dogs? Frontiers in Ecology and the Environment 4: 459-464.

Dodds, W. K., J. M. Blair, G. M. Henebry, J. K. Koelliker, R. RAMUNDO, AND C. M. TATE. 1996. Nitrogen transport from tallgrass prairie watersheds. Journal of Environmental Quality 25:973-981.

Dodds, W. K., W. Bouska, J. Eitzmann, T. Pilger, K. Pitts, A. Riley, J. Schloesser, AND D. Thornbrugh. 2009. Eutrophication of US freshwaters: analysis of potential economic damages. Environmental Science and Technology 43: 12-19.

DodDs, W. K., AND M. R. WhiLes. 2004. Quality and quantity of suspended particles in rivers: continent-scale patterns in the United States. Environmental Management 33: 355-367.

Duell, A. B. 1990. Effects of burning on infiltration, overland flow, and sediment loss on tallgrass prairie. MS Thesis, Kansas State University, Manhattan, Kansas.

FLORES, D. 1991. Bison ecology and bison diplomacy: the southern plains from 1800 to 1850 . Journal of American History 78:465-485.

Fox, J., AND S. WeIsberg. 2011. An R companion to applied regression. $2^{\text {nd }}$ edition. Sage Publications, New York.

Fritz, K. M., W. K. DodDS, AND J. PonTIUS. 1999. The effects of bison crossings on the macroinvertebrate community in a tallgrass prairie stream. American Midland Naturalist 141:253-265.

Fuhlendorf, S. D., D. M. Engle, J. Kerby, and R. Hamilton. 2009. Pyric herbivory: rewilding landscapes through the recoupling of fire and grazing. Conservation Biology 23: 589-598.

Greenwood, K. L., And B. M. McKenzie. 2001. Grazing effects on soil physical properties and the consequences for pastures: a review. Australian Journal of Experimental Agriculture 41:1231-1250.

Hothorn, T., K. Hornik, M. A. van de Wiel, and A. Zeileis. 2006. A lego system for conditional inference. American Statistician 60:257-263. 
Johnson, L. C., And J. R. Matchett. 2001. Fire and grazing regulate belowground processes in tallgrass prairie. Ecology 82:3377-3389.

KINDT, R., AND R. COE. 2005. Tree diversity analysis. A manual and software for common statistical methods for ecological and biodiversity studies. World Agroforestry Centre, Nairobi, Kenya.

KNAPP, A. K. 1998. Grassland dynamics: long-term ecological research in tallgrass prairie. Oxford University Press, New York.

Knapp, A. K., J. M. Blair, J. M. Briggs, S. L. Collins, D. C. Hartnett, L. C. Johnson, and E. G. Towne. 1999. The keystone role of bison in North American tallgrass prairie. BioScience 49:39-50.

Kondolf, G. M. 1993. Lag in stream channel adjustment to livestock exclosure, White Mountains, California. Restoration Ecology 1:226-230.

Larson, D. M., W. K. Dodds, K. E. Jackson, M. R. Whiles, and K. R. Winders. 2013. Ecosystem characteristics of remnant, headwater tallgrass prairie streams. Journal of Environmental Quality 42:239-249.

McMillan, B. R., M. R. Cottam, and D. W. Kaufman. 2000. Wallowing behavior of American bison (Bison bison) in tallgrass prairie: an examination of alternate explanations. American Midland Naturalist 144:159-167.

Meyer, G. A., J. L. Pierce, S. H. Wood, And A. J. T. Jull. 2001. Fire, storms, and erosional events in the Idaho batholith. Hydrological Processes 15:3025-3038.

Moody, J. A., AND D. A. Martin. 2001. Initial hydrologic and geomorphic response following a wildfire in the Colorado Front Range. Earth Surface Processes and Landforms 26:1049-1070.

Oksanen, J., F. G. Blanchet, R. Kindt, P. Legendre, P. R. Minchin, R. B. O’Hara, G. L. Simpson, P. Solymos, M. H. H. Stevens, and H. Wagner. 2011. vegan: community ecology package: ordination, diversity and dissimilarities. R Project for Statistical Computing, Vienna, Austria.

Olness, A., S. Smith, E. Rhoades, and R. Menzel. 1975. Nutrient and sediment discharge from agricultural watersheds in Oklahoma. Journal of Environmental Quality 4:331-336.

Oviatt, C. G. 1998. Geomorphology of Konza Prairie. Pages 35-47 in A. Knapp (editor). Grassland dynamics: long-term ecological research in tallgrass prairie. Oxford University Press, New York.

Roberts, D. W. 2010. Labdsv package, ordination and multivariate analysis for ecology. R Project for Statistical Computing, Vienna, Austria.

SHAW, J. H., AND M. LeE. 1997. Relative abundance of bison, elk, and pronghorn on the southern plains, 1806-1857. Plains Anthropologist 42:163-172.

Smith, H. G., G. J. Sheridan, P. N. J. LANe, ANd C. B. Sherwin. 2010. Paired Eucalyptus forest catchment study of prescribed fire effects on suspended sediment and nutrient exports in south-eastern Australia. International Journal of Wildland Fire 19:624-636.

Smith, R. A., R. B. Alexander, AND G. E. Schwarz. 2003. Natural background concentrations of nutrients in streams and rivers of the conterminous United States. Environmental Science and Technology 37:3039-3047.

Stebirns, G. L. 1981. Coevolution of grasses and herbivores. Annals of the Missouri Botanical Garden 68:75-86.

Stewart, O. C. 1951. Burning and natural vegetation in the United States. Geographical Review 41:317-320.

USEPA (US Environmental Protection Agency). 1997. Lake Michigan mass balance, methods compendium. Volume 3: LMMB 065 (ESS Method 340.2). US Environmental Protection Agency, Washington, DC.

van Langevelde, F., C. A. Van de Vijver, L. Kumar, V. D. Koppel, N. De Ridder, J. Van Andel, A. Skidmore, J. W. Hearne, L. Stroosnijder, W. J. Bond, H. H. T. Prins, And M. RIETKERK. 2003. Effects of fire and herbivory on the stability of savanna ecosystems. Ecology 84:337-350.

Vermeire, L. T., R. B. Mitchell, S. D. Fuhlendorf, and R. L. GILLEN. 2004. Patch burning effects on grazing distribution. Journal of Range Management 57:248-252.

Received: 1 August 2012 Accepted: 19 April 2013 